\title{
Adverse effects and non-adherence to antihypertensive medications in University of Gondar Comprehensive Specialized Hospital
}

Eyob Alemayehu Gebreyohannes ${ }^{*}$ D, Akshaya Srikanth Bhagavathula, Tamrat Befekadu Abebe, Yonas Getaye Tefera and Tadesse Melaku Abegaz

\begin{abstract}
Background: A considerable proportion of cardiovascular events could be attributed to poor adherence to antihypertensive medications. Adverse effects can be severe enough to affect adherence to antihypertensive medications. This study aimed to measure the contribution of adverse effects on antihypertensive medications adherence.

Methods: The study was conducted from May 1 to June 30, 2017, at the ambulatory clinic of University of Gondar Comprehensive Specialized Hospital (UOGCSH) in Gondar town. A binary logistic regression was performed to determine the significance of the association between adverse effects and adherence to antihypertensive medications. An institution-based cross-sectional study was conducted by administering a questionnaire to hypertensive patients who came for follow-up at the ambulatory clinic of UOGCSH. Level of adherence to antihypertensive medications was used as outcome measure.

Results: A total of 249 patients were included in the final analysis with a mean age of 56.51 years and a female majority (53\%). The following variables were identified as predictors of poor adherence: tiredness [AOR (95\% Cl): 3.802 (1.723-8.391), $p=0.001$, muscle pain [AOR (95\% Cl): 5.199 (1.407-19.214), $p=0.013$ ], poor sleep [AOR (95\% CI): 4.891 $(1.578-15.160), p=0.006$ ] and, believing that the symptoms were caused by antihypertensive medications [AOR (95\% Cl): $3.249(1.248-8.456), p=0.016]$.

Conclusion: Adverse effect significantly contributes to antihypertensive medication non-adherence among hypertensive patients.
\end{abstract}

Keywords: Hypertension, Antihypertensive medications, Adherence, Adverse effects, Gondar, Ethiopia

\section{Background}

The most important goal of antihypertensive drug treatment is to reduce renal and cardiovascular morbidity and mortality by lowering blood pressure (BP). To achieve this goal patients should be encouraged to adhere to the prescribed pharmacologic and non-pharmacologic management strategies [1]. A considerable proportion of cardiovascular events such as angina, myocardial infarction, chronic heart failure, kidney

\footnotetext{
* Correspondence: justeyob@gmail.com

School of Pharmacy, University of Gondar-College of Medicine and Health Sciences, Gondar, Ethiopia
}

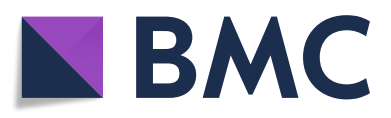

(c) The Author(s). 2019 Open Access This article is distributed under the terms of the Creative Commons Attribution 4.0 International License (http://creativecommons.org/licenses/by/4.0/), which permits unrestricted use, distribution, and reproduction in any medium, provided you give appropriate credit to the original author(s) and the source, provide a link to the Creative Commons license, and indicate if changes were made. The Creative Commons Public Domain Dedication waiver (http://creativecommons.org/publicdomain/zero/1.0/) applies to the data made available in this article, unless otherwise stated. premature mortality and disability, and increased cost of hospitalization could be attributed to poor adherence to antihypertensive medications and persistently elevated BP [2-5]. On the other hand, significantly lower systolic and diastolic BPs have been achieved by hypertensive patients reporting strict adherence to prescribed drug therapy than those who admit even an occasional lapse in taking their antihypertensive medications [6, 7]. In addition, an increased level of adherence to antihypertensive agents $(\geq 80 \%)$ provides a net economic gain by 
decreasing the occurrence of hypertension-associated complications $[4,5]$.

Patients report intentional and unintentional nonadherence. While unintentional nonadherence is a passive process whereby patients may be unconcerned or forgetful about adhering to their antihypertensive medications, intentional nonadherence, on the other hand, can be considered an active process whereby patients deliberately stray from adhering to their antihypertensive medication treatment [8]. Even though life-threatening adverse effects and hospitalization for adverse effects are rare occurrences, adverse effects such as cough, edema, flush, headache, increased urination, rapid pulse, wheezing/shortness of breath and dizziness can be severe enough to affect the utilization of antihypertensive medications [8-20]. The numbers of adverse effects reported by individual patients are also of paramount importance in patients' adherence to their antihypertensive medications [8].

A comparison of the answers of the patients and physicians on medication adherence showed that adherence may be overestimated by the doctors. This indicates that patients are usually less adherent to the prescribed medications than what their doctors' think [14]. Therefore, a properly formulated questionnaire can help distinguish adherent patients from those who are non-adherent [21].

Adherence to antihypertensive medications is a concern in the University of Gondar Comprehensive Specialized Hospital (UOGCSH) as evidenced by the low level of adherence. One-third (35.4\%) of hypertensive patients attending UOGCSH were found to be non-adherent to their prescribed anti-hypertensive treatment [22]. However, the contribution of adverse events for the low level of adherence remains unknown. Therefore, the aim of this study was to measure the contribution of adverse effects on antihypertensive medications adherence.

\section{Methods}

\section{Study setting and period}

The study was conducted from May 1 to June 30, 2017, at the ambulatory clinic of UOGCSH in Gondar town. Gondar is a historical town located in the northwest part of Ethiopia, $725 \mathrm{~km}$ from the capital city Addis Ababa.

\section{Study design}

An institution-based cross-sectional study was conducted by administering a questionnaire to hypertensive patients who came for follow-up at the ambulatory clinic of UOGCSH.

\section{Data collection procedures}

The data collection tool was adopted from the DuarteSilva et al. study [23]. In addition, since $80 \%$ has been used by several studies as a cut-off point for good adherence, the questionnaire has been modified to include this [24-27]. Before the data collection, the questionnaire was first translated into Amharic by one of the investigators (EAG) and then back-translated into English by the other investigator (TBA) for verifying accuracy. Discrepancies were dealt with a discussion. The questionnaire had been pretested on 25 hypertensive patients before it was administered to check if the patients were able to understand it. These patients were excluded from the final analyses and no modification was made on the questionnaire after the pretest.

The questionnaire was basically self-administered; however, for study participants who faced difficulty or who were illiterates, an interview was used as a means of data collection. Data on patients' current antihypertensive medication regimens were taken from their medical records.

Level of adherence was calculated by subtracting the number of missed doses (obtained from the questionnaire) from the total intended doses (obtained from medical records) and calculating the adherence out of $100 \%$. There were questions on the questionnaire stating: "Many patients have difficulties taking their medicines as the doctor recommended. In the past three months, there was any day or period of time when you did not take the drugs for blood pressure as recommended?" and "In a month, how many times did that happen?"

\section{Inclusion and exclusion criteria}

All hypertensive patients aged 18 years and above who came to the ambulatory clinic of UOGCSH and were taking one or more antihypertensive medications for the management of their high $\mathrm{BP}$ at least for 3 months were included in the study. The following patients were excluded from the study: patients who do not consent to participate; patients who didn't completely fill out the questionnaire.

Level of adherence to antihypertensive medications was used as an outcome measure. Sociodemographic characteristics, the antihypertensive medications used, perceived adverse effects by patients, whether patients spoke about adverse effects, whether patients think that perceived symptoms were caused by antihypertensive medications, and the non-pharmacologic management strategies taken were used as independent variables.

\section{Statistical analysis}

Descriptive statistics were used to present patient characteristics. Shapiro - Wilk and Levene's tests were 
performed to assess the data for normality and homogeneity. The four-item Likert scale was dichotomized into two: Never/Sometimes and Usually/Always. A binary logistic regression was performed to determine the significance of the association between adverse effects and adherence to antihypertensive medications. Variables with $p \leq 0.20$ in univariate were included to perform multivariate analysis. Similarly, significance of association between specific antihypertensive medications and adverse effects were determined using binary logistic regression analysis. All data analyses were done using the statistical package for social sciences (SPSS 20).

\section{Ethics approval}

Ethical clearance was obtained from the research ethical review committee of the school of Pharmacy, University of Gondar. Written informed consent was sought from each study participant and confidentiality of the information was assured in such a way that no disclosure of any information obtained from the participants in relation to the finding was made and the information was used for the research purpose only.

\section{Results}

A total of 249 patients were included in the final analysis with a mean age of 56.51 years and a female majority (53\%). Most of the study participants lived in urban areas and were married. The number of antihypertensive medications used by patients ranges from one to three. Nearly one-third of the study participants also used additional medications for the management of other chronic conditions (Table 1).

Hydrochlorothiazide (HCT) was the most commonly prescribed -medication, followed by enalapril and amlodipine (Fig. 1). The median (minimum-maximum) daily doses of HCT, enalapril, amlodipine, and nifedipine were $25 \mathrm{mg}$ (12.5-50), $5 \mathrm{mg}$ (2.5-20), $5 \mathrm{mg}$ [5-20], and $20 \mathrm{mg}$ (5-40), respectively.

Nearly one-third of patients had poor adherence $(<80 \%)$ to their antihypertensive medications. Forgetfulness (20.1\%) and fasting (5.6\%) were the two most commonly mentioned reasons for poor adherence (Table 2). Approximately $60 \%$ of the study participants didn't know if symptoms were caused by their antihypertensive medications. Among the study participants, $21.3 \%$ think that their symptoms were caused by their antihypertensive medications while $13.4 \%$ of the study participants reported that, symptoms caused them to change their medication administration behavior (Additional file 1).

Among the study participants, $43.37 \%$ were taking monotherapy while the remaining patients were on two or more combination antihypertensive medications. Thiazides, Thiazide/Angiotensin Converting Enzyme Inhibitors (ACEIs), and Thiazide/ACEIs/Calcium Channel
Table 1 Baseline characteristics of hypertensive patients attending UOGCSH $(N=249)$

\begin{tabular}{|c|c|}
\hline Characteristics & \\
\hline \multicolumn{2}{|l|}{ Age } \\
\hline Mean ( \pm standard deviation) & $56.51(11.004)$ \\
\hline \multicolumn{2}{|l|}{ Age at time of HTN diagnosis } \\
\hline Median (interquartile range) & $50(11)$ \\
\hline \multicolumn{2}{|c|}{ Duration of antihypertensive medication use (years) } \\
\hline Median (interquartile range) & $4(5)$ \\
\hline \multicolumn{2}{|l|}{ Sex N (\%) } \\
\hline Female & $132(53 \%)$ \\
\hline \multicolumn{2}{|l|}{ Residence N (\%) } \\
\hline Urban & $164(65.9 \%)$ \\
\hline \multicolumn{2}{|l|}{ Marital status N (\%) } \\
\hline Single & $22(8.8 \%)$ \\
\hline Married & $198(79.5 \%)$ \\
\hline Divorced & $12(4.8 \%)$ \\
\hline Widowed & $17(6.8 \%)$ \\
\hline \multicolumn{2}{|l|}{ Education level N (\%) } \\
\hline No formal education & 99 (39.8\%) \\
\hline Primary education & $67(26.9 \%)$ \\
\hline Secondary education & $32(12.9 \%)$ \\
\hline College and above & $51(20.5 \%)$ \\
\hline \multicolumn{2}{|l|}{ Smoking status N (\%) } \\
\hline Yes & $13(5.2 \%)$ \\
\hline \multicolumn{2}{|c|}{ Number of antihypertensive medications used } \\
\hline Median (Range) & $2(1-4)$ \\
\hline Other medication use N (\%) & $86(34.5 \%)$ \\
\hline
\end{tabular}

Blockers (CCBs) were the most commonly used single, two-drug, and three-drug therapies, respectively (Additional file 2). Twenty-five different types of adverse effects were reported by the study participants. Tiredness and dizziness were the two most commonly occurring adverse effects being reported by nearly half of the study participants as "Usually/Always" (Table 3).

Univariate analysis of binary logistic regression identified age, duration of antihypertensive medication use, and use of nifedipine and medications other than those used for management of hypertension as predictors of poor adherence. However, none of these were able to independently predict poor adherence to antihypertensive medications up on multivariate analysis. Multivariate analysis identified that patients who selected "Usually/Always" for tiredness [adjusted odds ratio (AOR) (95\% confidence interval (CI)): 3.802 (1.7238.391), $p=0.001$ ], muscle pain [AOR (95\% CI): 5.199 (1.407-19.214), $p=0.013$ ], and poor sleep [AOR $(95 \%$ CI): 4.891 (1.578-15.160), $p=0.006]$ were more likely to 


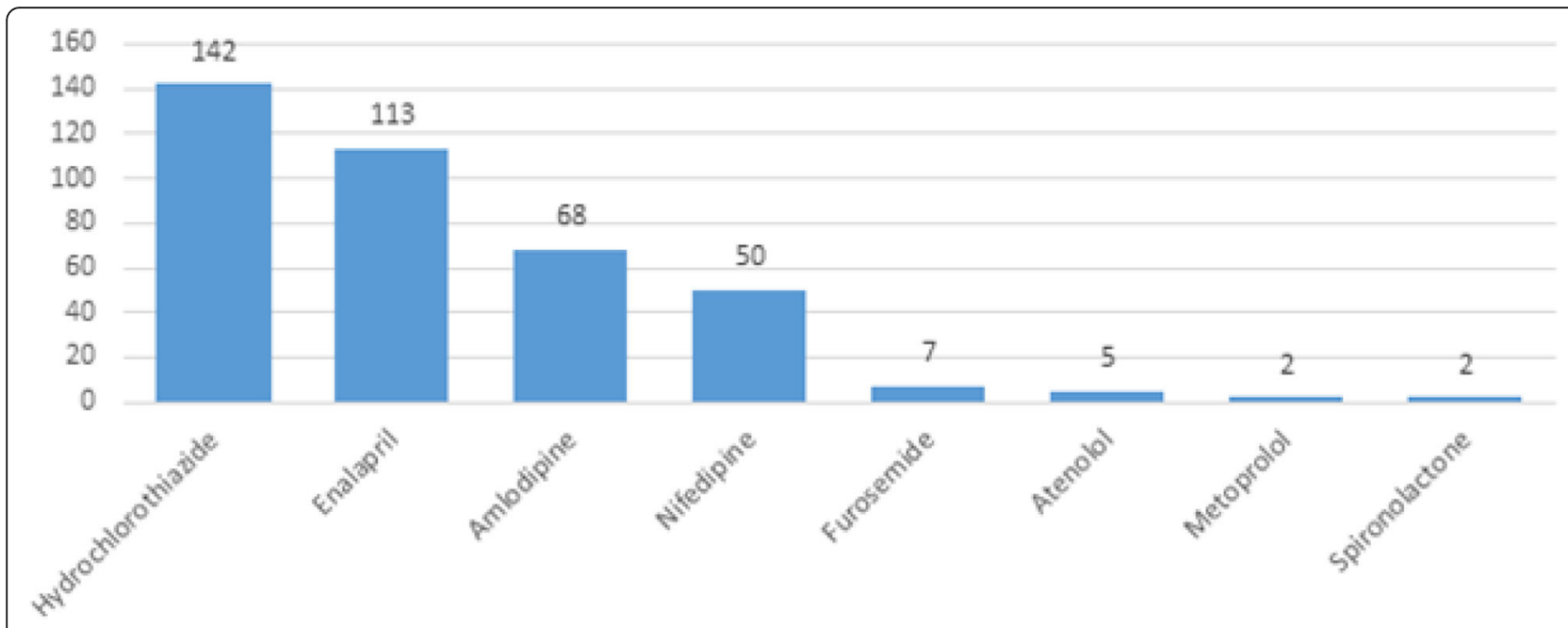

Fig. 1 The number of hypertensive patients using different antihypertensive medications at UOGCSH $(N=249)$

have poor adherence to their antihypertensive medication doses. In addition, patients who believe that the symptoms they experienced were caused by their antihypertensive medications were more likely to have poor adherence than patients who do not know [AOR (95\% CI): 3.249 (1.248-8.456), $p=0.016$ ]. More importantly, patients who reported that symptoms caused them to change their antihypertensive medication-taking behavior were more likely to have poor adherence to their antihypertensive medication doses $[\mathrm{AOR}(95 \% \mathrm{CI})$ :

Table 2 Adherence to antihypertensive medications among hypertensive patients attending UOGCSH $(N=249)$

\begin{tabular}{ll}
\hline & Number (Percent) \\
\hline Level of adherence & $156(62.7 \%)$ \\
Good $(\geq 80 \%)$ & $93(37.3 \%)$ \\
Rearon $(<80 \%)$ & \\
Forgetfulness & $50(20.1 \%)$ \\
Economic reasons & $6(2.4 \%)$ \\
Drug cause discomfort or malaise & $6(2.4 \%)$ \\
BP was normal & $1(0.4 \%)$ \\
BP was too low & $3(1.2 \%)$ \\
Unavailability of drugs in the market & $7(2.8 \%)$ \\
Fasting & $14(5.6 \%)$ \\
Traveling & $5(2.0 \%)$ \\
Forgetfulness and economic reasons & $1(0.4 \%)$ \\
Importance of missed dose on BP & \\
None & $160(64.3 \%)$ \\
Little & $31(12.4 \%)$ \\
Some & $25(10.0 \%)$ \\
Many & $33(13.3 \%)$ \\
\hline
\end{tabular}

16.104 (4.164-62.290), $p=0.000]$. On the other hand, patients who reported having regular physical exercise were more likely to have good adherence [AOR (95\% CI): 0.170 (0.072-0.402), $p=0.000$ ] (Table 4).

Binary logistic regression identified statistically significant associations between the antihypertensive medications and associated ADRs. Nausea, constipation, palpitation, swollen feet or legs, cold hands or feet, cramps, persistent dry cough, skin rash, frequent urination, and decreased sexual desires were associated with one or more of the following antihypertensive medications: furosemide, hydrochlorothiazide, amlodipine, nifedipine, atenolol, and enalapril (Table 5).

\section{Discussion}

This study tried to see whether adverse effects due to antihypertensive medications influence the medicationtaking behavior of hypertensive patients. Based on the findings of this study, the medication-taking behavior of the patients was negatively affected by antihypertensive medications adverse effects. In general, nearly a third of patients reported poor adherence. One-fifth of the study participants think that their symptoms were caused by their antihypertensive medications and another $13.4 \%$ of the study participants reported that, symptoms caused them to change their medication administration behavior.

Several other studies reported that medication-taking behavior can be affected by adverse effects [26, 28-35]. Grassi et al. reported that up to more than half of antihypertensive medication discontinuation can be attributed to adverse effects [26]. In another study, Grégoire et al. reported that patients who perceived adverse effects from their antihypertensive medications were 1.91 times more likely to discontinue their initial antihypertensive medications [31]. 
Table 3 Adverse effects experienced by hypertensive patients attending UOGCSH $(N=249)$

\begin{tabular}{|c|c|c|c|c|c|c|}
\hline \multirow[t]{2}{*}{ Adverse effects } & \multicolumn{2}{|c|}{ Good adherence $(N=156)$} & \multicolumn{2}{|c|}{ Poor adherence $(N=93)$} & \multicolumn{2}{|l|}{ Total $(N=249)$} \\
\hline & $\begin{array}{l}\text { Never/ Sometimes } \\
\text { N (\%) }\end{array}$ & $\begin{array}{l}\text { Usually/ Always } \\
\text { N (\%) }\end{array}$ & $\begin{array}{l}\text { Never/ Sometimes } \\
\text { N (\%) }\end{array}$ & $\begin{array}{l}\text { Usually/ Always } \\
N(\%)\end{array}$ & $\begin{array}{l}\text { Never/ Sometimes } \\
\text { N (\%) }\end{array}$ & $\begin{array}{l}\text { Usually/ Always } \\
\text { N (\%) }\end{array}$ \\
\hline Tiredness & $98(62.8)$ & $58(37.2)$ & $32(34.4)$ & $61(65.6)$ & $130(52.2)$ & $119(47.8)$ \\
\hline Sweats & $138(88.5)$ & $18(11.5)$ & $73(78.5)$ & $20(81.5)$ & $211(84.7)$ & $38(15.3)$ \\
\hline Gripes & $142(91.0)$ & $14(9.0)$ & $80(86.0)$ & $13(14.0)$ & $222(89.2)$ & $27(10.8)$ \\
\hline Nausea & $140(89.7)$ & $16(10.3)$ & $77(82.8)$ & $16(17.2)$ & $217(87.1)$ & $32(12.9)$ \\
\hline Diarrhea & $152(97.4)$ & $4(2.6)$ & $92(98.9)$ & $1(1.1)$ & $244(88.0)$ & $5(2.0)$ \\
\hline Constipation & $131(84.0)$ & $25(16.0)$ & $82(88.2)$ & $11(11.8)$ & $212(85.5)$ & $36(14.5)$ \\
\hline Palpitations & $114(73.1)$ & $42(26.9)$ & $53(57.0)$ & $40(43.0)$ & $167(67.1)$ & $82(32.9)$ \\
\hline Swollen feet or legs & $120(76.9)$ & $36(23.1)$ & $67(72.0)$ & $26(28.0)$ & $187(75.1)$ & $62(24.9)$ \\
\hline Cold hands or feet & $145(92.9)$ & $11(7.1)$ & 75 (80.6) & $18(19.4)$ & $220(88.4)$ & 29 (11.6) \\
\hline Muscle pain & $146(93.6)$ & $10(6.4)$ & 77 (82.8) & $16(17.2)$ & $223(89.6)$ & $26(10.4)$ \\
\hline Cramps & $146(93.6)$ & $10(6.4)$ & $82(88.2)$ & $11(11.8)$ & $228(91.6)$ & $21(8.4)$ \\
\hline Headaches & $91(58.3)$ & $65(41.7)$ & $45(48.4)$ & $48(51.6)$ & $136(54.6)$ & $113(45.4)$ \\
\hline Dizziness & $83(53.2)$ & $73(46.8)$ & $47(50.5)$ & $46(49.5)$ & $130(52.2)$ & $119(47.8)$ \\
\hline Anxiety & $142(91.0)$ & $14(9.0)$ & $78(83.9)$ & $15(16.1)$ & $220(88.4)$ & $29(11.6)$ \\
\hline Sadness & $143(91.7)$ & $13(8.3)$ & $81(87.1)$ & $12(12.9)$ & $224(90)$ & $25(10.0)$ \\
\hline Sleep poorly & $136(87.2)$ & $20(12.8)$ & $71(76.3)$ & $22(23.7)$ & $207(83.1)$ & $42(16.9)$ \\
\hline $\begin{array}{l}\text { Shortness of breath or breathing } \\
\text { difficulty }\end{array}$ & $142(91.0)$ & $14(9.0)$ & $84(90.3)$ & $9(9.7)$ & $226(90.8)$ & $23(9.2)$ \\
\hline Persistent dry cough & $124(79.5)$ & $32(20.5)$ & $70(75.3)$ & $23(24.7)$ & $194(77.9)$ & $55(22.1)$ \\
\hline Itching & $146(93.6)$ & $10(6.4)$ & 87 (93.5) & $6(6.5)$ & $233(93.6)$ & $16(6.4)$ \\
\hline Skin rash & $151(96.8)$ & $5(3.2)$ & $84(90.3)$ & $9(9.7)$ & $235(94.4)$ & $14(5.6)$ \\
\hline Swollen or red face & $150(96.2)$ & $6(3.8)$ & $92(98.9)$ & $1(1.1)$ & $242(97.2)$ & $7(2.8)$ \\
\hline Dry mouth & $142(91.0)$ & $14(9.0)$ & $82(88.2)$ & $11(11.8)$ & $224(90)$ & $25(10.0)$ \\
\hline Frequent urination & $98(62.8)$ & $58(37.2)$ & $61(65.6)$ & $32(34.4)$ & 159() & $90(36.1)$ \\
\hline $\begin{array}{l}\text { Decreased sexual desire or ability } \\
\text { sexual }\end{array}$ & $126(80.8)$ & $30(19.2)$ & $83(89.2)$ & $10(10.8)$ & 208() & $40(16.1)$ \\
\hline Blurred vision & $155(99.4)$ & $1(0.6)$ & $93(100.0)$ & $0(0.0)$ & 248() & $1(0.4)$ \\
\hline
\end{tabular}

One Palestinian study also reported a 4.6 fold increase in the rate of poor adherence in patients who perceived adverse effects [24]. Even though none of the study participants in the current study discontinued their antihypertensive medications, a three-fold increase in the rates of non-adherence were observed.

In a systematic review of qualitative studies, tiredness, urinary frequency, ankle swelling, lethargy, and impotence were mentioned as troublesome adverse effects [33] while tiredness, muscle pain, and poor sleep were associated with poor adherence in the current study. On the other hand, patients who reported to have regular physical exercise were more likely to be adherent to their antihypertensive medications. Better knowledge about the disease and its management could contribute to better adherence by these patients.

Efforts that focus on improving the knowledge and awareness of patients is crucial for optimal treatment outcomes especially in patients with diseases such as hypertension. Hypertensive patients do not usually present with symptoms but can ultimately experience serious cardiovascular consequences. The fact that they don't usually have symptoms coupled with the adverse effects can discourage them to be adherent to their antihypertensive medications [29, 32, 35].

Forgetfulness was the most commonly mentioned reason for poor adherence to antihypertensive medications. This has been reported in other studies [24, 28, 29, 32]. Fasting has been reported as the second most common cause of poor adherence. Therefore, depending on each patient's case, clinicians should work closely with patients and select the appropriate regimen and time of administration in order to improve adherence.

$\mathrm{HCT}$, enalapril, and amlodipine were the most commonly prescribed medications. While it is believed that there might be differences in the adverse effect 
Table 4 Predictors of poor adherence to antihypertensive medications among hypertensive patients attending UOGCSH ( $N=249)$

\begin{tabular}{|c|c|c|c|c|}
\hline Variables & Crude odds ratio (COR) $(95 \% \mathrm{Cl})$ & $p$-value & AOR $(95 \% \mathrm{Cl})$ & $p$-value \\
\hline \multicolumn{5}{|l|}{ Age } \\
\hline Years & $1.025(1.000-1.050)$ & 0.048 & $0.994(0.959-1.030)$ & 0.738 \\
\hline \multicolumn{5}{|l|}{ Duration of antihypertensive medication use } \\
\hline Years & $1.122(1.056-1.193)$ & 0.000 & $1.080(0.996-1.170)$ & 0.062 \\
\hline Number of antihypertensive medications used & $1.478(0.976-2.239)$ & 0.065 & $1.496(0.804-2.784)$ & 0.204 \\
\hline Hydrochlorothiazide & $0.659(0.392-1.109)$ & 0.116 & $0.837(0.404-1.732)$ & 0.632 \\
\hline Nifedipine & $2.865(1.502-5.465)$ & 0.001 & $2.389(0.900-6.340)$ & 0.080 \\
\hline \multicolumn{5}{|l|}{ Other medications } \\
\hline Yes & $1.870(1.090-3.207)$ & 0.023 & $2.633(0.598-11.587)$ & 0.200 \\
\hline Number of other medications & $1.262(0.949-1.678)$ & 0.109 & $0.876(0.401-1.917)$ & 0.741 \\
\hline \multicolumn{5}{|l|}{ Tiredness } \\
\hline Yes & $3.122(1.825-5.348)$ & 0.000 & $3.802(1.723-8.391)$ & 0.001 \\
\hline \multicolumn{5}{|l|}{ Sweats } \\
\hline Yes & $2.055(1.023-4.128)$ & 0.043 & $0.790(0.266-2.342)$ & 0.670 \\
\hline \multicolumn{5}{|l|}{ Nausea } \\
\hline Yes & $1.779(0.843-3.756)$ & 0.131 & $0.654(0.190-2.260)$ & 0.503 \\
\hline \multicolumn{5}{|l|}{ Palpitation } \\
\hline Yes & 1.995 (1.159-3.432) & 0.013 & $2.014(0.790-5.137)$ & 0.143 \\
\hline \multicolumn{5}{|l|}{ Cold hands and feet } \\
\hline Yes & 3.098 (1.391-6.899) & 0.006 & $1.676(0.463-6.064)$ & 0.431 \\
\hline \multicolumn{5}{|l|}{ Muscle pain } \\
\hline Yes & 2.971 (1.286-6.864) & 0.011 & 5.199 (1.407-19.214) & 0.013 \\
\hline \multicolumn{5}{|l|}{ Cramps } \\
\hline Yes & $1.918(0.781-4.711)$ & 0.155 & $3.073(0.632-14.933)$ & 0.164 \\
\hline \multicolumn{5}{|l|}{ Headache } \\
\hline Yes & $1.444(0.860-2.424)$ & 0.164 & $1.062(0.454-2.488)$ & 0.889 \\
\hline \multicolumn{5}{|l|}{ Anxiety } \\
\hline Yes & $1.909(0.876-4.162)$ & 0.104 & $0.906(0.247-3.331)$ & 0.882 \\
\hline \multicolumn{5}{|l|}{ Sleep poorly } \\
\hline Yes & $2.061(1.054-4.029)$ & 0.035 & 4.891 (1.578-15.160) & 0.006 \\
\hline \multicolumn{5}{|l|}{ Skin rash } \\
\hline Yes & 3.171 (1.029-9.774) & 0.044 & $2.132(0.373-12.193)$ & 0.395 \\
\hline \multicolumn{5}{|l|}{ Decreased sexual desire } \\
\hline Yes & $0.494(0.229-1.065)$ & 0.072 & $0.643(0.203-2.043)$ & 0.454 \\
\hline Number of adverse effects & $1.140(1.039-1.250)$ & 0.005 & $0.776(0.592-1.017)$ & 0.066 \\
\hline \multicolumn{5}{|l|}{ Symptoms are caused by medications } \\
\hline I don't know & 1 & & 1 & \\
\hline Yes & $1.348(0.669-2.714)$ & 0.403 & $3.249(1.248-8.456)$ & 0.016 \\
\hline No & $2.141(1.131-4.049)$ & 0.019 & $1.720(0.673-4.392)$ & 0.257 \\
\hline Symptoms caused to change or stop medications & $10.554(4.169-26.717)$ & 0.000 & $16.104(4.164-62.290)$ & 0.000 \\
\hline \multicolumn{5}{|l|}{ Regular exercise } \\
\hline Yes & $0.363(0.209-0.632)$ & 0.000 & $0.170(0.072-0.402)$ & 0.000 \\
\hline
\end{tabular}


Table 5 Relationship between ADRs and specific antihypertensive medications

\begin{tabular}{|c|c|c|c|}
\hline ADRs & Medications & COR & $p$-value \\
\hline Nausea & Furosemide & $\begin{array}{l}5.509 \\
(1.173-25.860)\end{array}$ & 0.031 \\
\hline Constipation & Furosemide & $\begin{array}{l}4.750 \\
(1.017-22.186)\end{array}$ & 0.048 \\
\hline \multirow[t]{2}{*}{ Palpitation } & Amlodipine & $\begin{array}{l}2.136 \\
(1.200-3.802)\end{array}$ & 0.010 \\
\hline & Furosemide & $\begin{array}{l}5.357 \\
(1.017-28.231)\end{array}$ & 0.048 \\
\hline \multirow[t]{3}{*}{ Swollen feet or legs } & Amlodipine & $\begin{array}{l}2.263 \\
(1.228-4.169)\end{array}$ & 0.009 \\
\hline & Nifedipine & $\begin{array}{l}2.224 \\
(1.145-4.317)\end{array}$ & 0.018 \\
\hline & Atenolol & $\begin{array}{l}12.828 \\
(1.406-17.055)\end{array}$ & 0.024 \\
\hline \multirow[t]{2}{*}{ Cold hands or feet } & Furosemide & $\begin{array}{l}6.231 \\
(1.321-29.393)\end{array}$ & 0.021 \\
\hline & Atenolol & $\begin{array}{l}12.577 \\
(2.008-78.782)\end{array}$ & 0.007 \\
\hline \multirow[t]{3}{*}{ Cramps } & Nifedipine & $\begin{array}{l}3.421 \\
(1.352-8.653)\end{array}$ & 0.009 \\
\hline & Amlodipine & $\begin{array}{l}3.329 \\
(1.435-7.723)\end{array}$ & 0.005 \\
\hline & Enalapril & $\begin{array}{l}2.533 \\
(1.271-5.044)\end{array}$ & 0.008 \\
\hline \multirow[t]{2}{*}{ Persistent dry cough } & Amlodipine & $\begin{array}{l}0.448 \\
(0.206-0.974)\end{array}$ & 0.043 \\
\hline & Enalapril & $\begin{array}{l}6.348 \\
(3.140-12.831)\end{array}$ & $<0.001$ \\
\hline Skin rash & Furosemide & $\begin{array}{l}7.667 \\
(1.346-43.658)\end{array}$ & 0.022 \\
\hline \multirow[t]{2}{*}{ Frequent urination } & Hydrochlorothiazide & $\begin{array}{l}6.866 \\
(3.629-12.988)\end{array}$ & $<0.001$ \\
\hline & Nifedipine & $\begin{array}{l}0.428 \\
(0.207-0.886)\end{array}$ & 0.022 \\
\hline \multirow[t]{2}{*}{ Decreased sexual desire } & Hydrochlorothiazide & $\begin{array}{l}4.325 \\
(1.831-10.216)\end{array}$ & 0.001 \\
\hline & Enalapril & $\begin{array}{l}0.458 \\
(0.221-0.950)\end{array}$ & 0.036 \\
\hline
\end{tabular}

profiles of different antihypertensive medications, no difference was observed in the level of adherence among patients different antihypertensive medications. On the other hand, hypertensive patients usually present with other chronic conditions for which they receive other medications. This increases the pill burden and complexity of regimens and has been attributed to poor adherence. In the current study, $34.5 \%$ patients used medications for the management of other chronic conditions. While this decreased the rate of adherence to antihypertensive medications upon univariate analysis, it failed to independently predict adherence upon multivariate analysis.
Just below half of the study participants (43.37\%) were taking monotherapy while the remaining patients were on two or more combination antihypertensive medications. The complexity of medication regimens including the number of antihypertensive medications was associated with poor adherence [28, 29]. However, the number of medications was not found to be statistically significant in predicting adherence in the current study. Despite this, promoting the use of fixed-dose combination antihypertensive medications (FDC) may improve medication adherence. Several studies reported advantages of FDC in terms of reducing adverse effects and simplifying regimens and thereby improving adherence [36]. However, availability of these FDC is also another issue in the current set up. On the other hand, selecting antihypertensive medications with better safety profile can help improve medication adherence. Studies reported that Angiotensin II Receptor Blockers (ARBs) have similar, if not better, safety profile than other antihypertensive classes and can improve medication adherence in hypertensive patients $[26,29,36]$. None of the study participants in the current study received ARBs and the use of these medications might be hindered by availability and affordability issues. ACEIs are better tolerated than most other antihypertensive medications; hence, they could be preferably used in the absence of ARBs [26].

Adherence to antihypertensive medications should be stressed as it is associated with poor outcomes. It has been associated with the inability to achieve BP control [26] and a significant increase in the risk for all-cause mortality and hospitalization due to cardiovascular events (hazard ratio $=1.57$ ) [7]. This necessitates efforts to improve medication adherence. One effort could be involving pharmacists in direct patient care as it has been demonstrated that pharmacist-led interventions improve antihypertensive medication adherence and BP control [37].

Interpretation of the findings of this study should be in light of the following limitations. This is a single-center cross-sectional study with small sample size and hence generalization to other settings should be done with caution. In addition, the study relied on patients reports of adverse reactions and may be subject to recall bias as it requires recalling missed doses in the past 3 months. It is also impossible to differentiate whether the adverse effects were due to the antihypertensive medications or other medications the patients were taking.

Statistically significant associations were identified among antihypertensive medications and a number of ADRs. As one might expect from its pharmacologic action, hydrochlorothiazide was associated with a six-fold increase in the number of patients experiencing frequent urination. As reported from clinical trials [38, 39], enalapril use was associated with cough. Other ADRs include cold hands or feet 
with furosemide and atenolol and swollen feet or legs with CCBs (amlodipine and nifedipine) and atenolol. In addition, furosemide was associated with nausea, constipation, palpitation, and skin rash.

\section{Conclusion}

Adverse effect significantly contributes to antihypertensive medication non-adherence in hypertensive patients. Most patients don't know if their symptoms were due to their antihypertensive medications. However, patients who thought that their symptoms were due to the antihypertensive medications they were taking tend to be non-adherent. Patients should be counseled about adverse effects common to their antihypertensive medications and should be directly involved in the decision process. Studies with prospective study designs should be done in the future to help better understand the association between adverse effects and non-adherence.

\section{Abbreviations}

ACEls: Angiotensin converting enzyme inhibitors; AOR: Adjusted odds ratio; ARB: Angiotensin II receptor blockers; BP: Blood pressure; CCBs: Calcium channel blockers; COR: Crude odds ratio; FDC: Fixed dose combination; SPSS: Statistical package for social science; UOGCSH: University of Gondar Comprehensive Specialized Hospital

\section{Acknowledgements}

We would like to acknowledge the school of pharmacy for supporting us during conducting this study. We also would like to thank individuals who participated in the data collection procedure.

\section{Funding}

There was no funding source.

\section{Availability of data and materials}

All data and materials used for the analysis of this review are included in this and the supporting documents.

\section{Authors' contributions}

EAG conceived the study, designed the study protocol, collected, entered, analyzed, and interpreted the data, conducted a literature review, and drafted the final manuscript. ASB, TBA, YGT, and TMA reviewed the study protocol, supervised the study, and conducted a literature review. All authors read and approved the final manuscript

\section{Ethics approval and consent to participate}

Ethical clearance was obtained from the research ethical review committee of the school of Pharmacy, University of Gondar. Written informed consent was sought from each study participant and confidentiality of the information was assured in such a way that no disclosure of any information obtained from the participants in relation to the finding was made and the information was used for the research purpose only.

\section{Consent for publication}

Not applicable.

\section{Competing interests}

The authors' declare that they have no competing interests.

\section{Publisher's Note}

Springer Nature remains neutral with regard to jurisdictional claims in published maps and institutional affiliations.
Received: 13 August 2018 Accepted: 17 December 2018

Published online: 15 January 2019

\section{References}

1. Chobanian AV, Bakris GL, Black HR, Cushman WC, Green LA, Izzo JL Jr, et al. The seventh report of the joint national committee on prevention, detection, evaluation, and treatment of high blood pressure: the JNC 7 report. JAMA. 2003;289(19):2560-71.

2. Chowdhury R, Khan H, Heydon E, Shroufi A, Fahimi S, Moore C, et al. Adherence to cardiovascular therapy: a meta-analysis of prevalence and clinical consequences. Eur Heart J. 2013;34(38):2940-8.

3. Dragomir A, Côté R, Roy L, Blais L, Lalonde L, Bérard A, et al. Impact of adherence to antihypertensive agents on clinical outcomes and hospitalization costs. Med Care. 2010;48(5):418-25.

4. World Health Organization. Prevention of cardiovascular disease: guidelines for assessment and management of cardiovascular risk. 2007 Available from: http://apps.who.int/iris/bitstream/handle/10665/43685/9789241547178_eng. pdf;jsessionid=26CDD2C8C638CCBD9CD27371D22A1F3C? sequence $=1$. [Cited 4 August 2017]

5. World Health Organization. A global brief on hypertension: silent killer, global public health crisis. 2013. Available from: https://www.who.int/ cardiovascular_diseases/publications/global_brief_hypertension/en/. [Cited 4 August 2017]

6. Kardas $P$, Lewek $P$, Matyjaszczyk M. Determinants of patient adherence: a review of systematic reviews. Front Pharmacol. 2013;4:91.

7. Shin S, Song H, Oh S-K, Choi KE, Kim H, Jang S. Effect of antihypertensive medication adherence on hospitalization for cardiovascular disease and mortality in hypertensive patients. Hypertens Res. 2013;36(11):1000-5.

8. Lowry KP, Dudley TK, Oddone EZ, Bosworth HB. Intentional and unintentional nonadherence to antihypertensive medication. Ann Pharmacother. 2005:39(7-8):1198-203.

9. Black H, Graff A, Shute D, Stoltz R, Ruff D, Levine J, et al. Valsartan, a new angiotensin II antagonist for the treatment of essential hypertension: efficacy, tolerability and safety compared to an angiotensin-converting enzyme inhibitor, lisinopril. J Hum Hypertens. 1997:11(8):483-9.

10. Curb JD, Borhani NO, Blaszkowski TP, Zimbaldi N, Fotiu S, Williams W. Long-term surveillance for adverse effects of antihypertensive drugs. JAMA. 1985;253(22):3263-8.

11. Lakhdar R, Al-Mallah MH, Lanfear DE. Safety and tolerability of angiotensin-converting enzyme inhibitor versus the combination of angiotensin-converting enzyme inhibitor and angiotensin receptor blocker in patients with left ventricular dysfunction: a systematic review and meta-analysis of randomized controlled trials. J Card Fail. 2008; 14(3):181-8.

12. Morimoto T, Gandhi TK, Fiskio JM, Seger AC, So JW, Cook EF, et al. An evaluation of risk factors for adverse drug events associated with angiotensinconverting enzyme inhibitors. J Eval Clin Pract. 2004;10(4):499-509.

13. Bardage C, Isacson DG. Self-reported side-effects of antihypertensive drugs: an epidemiological study on prevalence and impact on health-state utility. Blood Press. 2000;9(6):328-34.

14. Düsing $R$, Weisser $B$, Mengden $T$, Vetter $H$. Changes in antihypertensive therapy-the role of adverse effects and compliance. Blood Press. 1998; 7(5-6):313-5.

15. Fletcher AE, Bulpitt CJ, Chase DM, Collins WC, Furberg CD, Goggin TK, et al. Quality of life with three antihypertensive treatments. Cilazapril Atenolol Nifedipine Hypertension. 1992;19(6 Pt 1):499-507.

16. Israili ZH, Hall WD. Cough and angioneurotic edema associated with angiotensin-converting enzyme inhibitor therapy. Ann Intern Med. 1992; 117(3):234-42.

17. MacCarthy EP, Bloomfield SS. Labetalol: a review of its pharmacology, pharmacokinetics, clinical uses and adverse effects. Pharmacotherapy. 1983: 3(4):193-217.

18. Messerli FH. Vasodilatory edema: a common side effect of antihypertensive therapy. Curr Cardiol Rep. 2002;4(6):479-82.

19. Olsen H, klemetsrud T, Stokke HP, Tretli S, Westheim A. Adverse drug reactions in current antihypertensive therapy: a general practice survey of 2586 patients in Norway. Blood Press. 1999;8(2):94-101.

20. Saunders E, Weir MR, Kong BW, Hollifield J, Gray J, Vertes V, et al. A comparison of the efficacy and safety of a $\beta$-blocker, a calcium channel blocker, and a converting enzyme inhibitor in hypertensive blacks. Arch Intern Med. 1990;150(8):1707-13. 
21. Fodor GJ, Kotrec M, Bacskai K, Dorner T, Lietava J, Sonkodi S, et al. Is interview a reliable method to verify the compliance with antihypertensive therapy? An international central-European study. J Hypertens. 2005;23(6):1261-6.

22. Ambaw AD, Alemie GA, Mengesha ZB. Adherence to antihypertensive treatment and associated factors among patients on follow up at University of Gondar Hospital, Northwest Ethiopia. BMC Public Health. 2012;12(1):282.

23. Duarte-Silva D, Figueiras A, Herdeiro MT, Rodrigues AT, Branco FS, Polonia J, et al. PERSYVE-design and validation of a questionnaire about adverse effects of antihypertensive drugs. Pharm Pract. 2014;12(2):396.

24. Al-Ramahi R. Adherence to medications and associated factors: a crosssectional study among Palestinian hypertensive patients. J Epidemiol Glob Health. 2015;5(2):125-32.

25. Ghembaza M, Senoussaoui Y, Kendouci Tani M, Meguenni K. Impact of patient knowledge of hypertension complications on adherence to antihypertensive therapy. Curr Hypertens Rev. 2014;10(1):41-8.

26. Grassi G, Seravalle G, Mancia G. Cardiovascular consequences of poor compliance to antihypertensive therapy. Blood Press. 2011;20(4):196-203.

27. Nuesch R, Schroeder K, Dieterle T, Martina B, Battegay E. Relation between insufficient response to antihypertensive treatment and poor compliance with treatment: a prospective case-control study. BMJ. 2001;323(7305):142-6.

28. AlGhurair SA, Hughes CA, Simpson SH, Guirguis LM. A systematic review of patient self-reported barriers of adherence to antihypertensive medications using the World Health Organization multidimensional adherence model. J Clin Hypertens. 2012;14(12):877-86.

29. Burnier M. Medication adherence and persistence as the cornerstone of effective antihypertensive therapy. Am J Hypertens. 2006;19(11):1190-6.

30. Dharmarajan TS, Dharmarajan L. Tolerability of antihypertensive medications in older adults. Drugs Aging. 2015;32(10):773-96.

31. Grégoire J-P, Moisan J, Guibert R, Ciampi A, Milot A, Gaudet M, et al. Determinants of discontinuation of new courses of antihypertensive medications. J Clin Epidemiol. 2002;55(7):728-35.

32. Hong TB, Oddone EZ, Dudley TK, Bosworth HB. Medication barriers and anti-hypertensive medication adherence: the moderating role of locus of control. Psychol Health Med. 2006;11(1):20-8.

33. Marshall IJ, Wolfe CD, McKevitt C. Lay perspectives on hypertension and drug adherence: systematic review of qualitative research. BMJ. 2012;345: e3953.

34. Schroeder K, Fahey T, Ebrahim S. Interventions for improving adherence to treatment in patients with high blood pressure in ambulatory settings. Cochrane Database Syst Rev. 2004;2:CD004804.

35. Schroeder K, Fahey T, Ebrahim S. How can we improve adherence to blood pressure-lowering medication in ambulatory care?: systematic review of randomized controlled trials. Arch Intern Med. 2004;164(7):722-32.

36. Handler J. Quality of life and antihypertensive drug therapy. J Clin Hypertens. 2005;7(5):274-85.

37. Morgado M, Morgado S, Mendes L, Pereira L, Castelo Branco M. Pharmacist interventions to enhance blood pressure control and adherence to antihypertensive therapy: review and meta-analysis. AJHP. 2011;68:241-53.

38. Rake EC, Breeze E, Fletcher AE. Quality of life and cough on antihypertensive treatment: a randomised trial of eprosartan, enalapril and placebo. J Hum Hypertens. 2001;15(12):863.

39. Breeze E, Rake EC, Donoghue MD, Fletcher AE. Comparison of quality of life and cough on eprosartan and enalapril in people with moderate hypertension. J Hum Hypertens. 2001;15(12):857.

Ready to submit your research? Choose BMC and benefit from:

- fast, convenient online submission

- thorough peer review by experienced researchers in your field

- rapid publication on acceptance

- support for research data, including large and complex data types

- gold Open Access which fosters wider collaboration and increased citations

- maximum visibility for your research: over $100 \mathrm{M}$ website views per year

At BMC, research is always in progress.

Learn more biomedcentral.com/submissions 